\title{
Colour pattern polymorphism in Silurian nautiloid Phragmoceras Broderip, 1839
}

\author{
VOJTĚCH TUREK \& ŠTĚPÁN MANDA
}

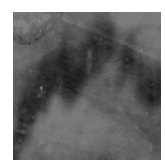

\begin{abstract}
Flamboyant colour pattern polymorphism documented in Silurian nautiloid Phragmoceras has not been observed in any other nautiloid genus. Two specimens of $P$. imbricatum Barrande, one from the early Ludlow of Bohemia and the second from the late Wenlock of England display quite different shell coloration: narrow, densely spaced longitudinal bands subparallel to the shell axis, combined with narrower transversal bands versus transverse bands running laterally obliquely to growth lamellae. Two additional types of colouration have been observed in several specimens of Phragmoceras from the early Wenlock and late Ludlow of Gotland. The colour pattern in P. eurystoma flexibile Hedström consists of zigzags bands around the whole circumference of the shell. In contrast, distinct colour bands following growth lines along the whole circumference of the shell, like that in the Cretaceous nautilid Eutrephoceras, are characteristic in $P$. dubium Hedström. If pigmentation pattern served as a form of crypsis, then the quite different types of coloration in Phragmoceras indicate different solutions of this problem. Colour pattern has been regarded as a useful tool also for taxonomic purposes in nautiloid cephalopods. Nevertheless, the colour polymorphism in Phragmoceras suggests the limited significance of this feature for the taxonomy of nautiloids. Some other remarkable cases of colour variations in Silurian nautiloids are discussed. Changes in colour pattern most probably correspond with depth inhabited; nautiloids that occupied shallow water environments display rather light coloured shells in comparison with forms inhabiting a deeper water setting. $\bullet$ Key words: Cephalopoda, Nautiloidea, colour pattern, polymorphism, Silurian.
\end{abstract}

TUREK, V. \& MANDA, S̆. 2011. Colour pattern polymorphism in Silurian nautiloid Phragmoceras Broderip, 1839. Bulletin of Geosciences 86(1), 91-105 (9 figures, 1 table). Czech Geological Survey, Prague. ISSN 1214-1119. Manuscript received November 5, 2010; accepted in revised form December 14, 2010; published online March 10, 2011; issued March 14, 2011.

Vojtěch Turek, National Museum, Department of Palaeontology, Václavské náměstí 68, 11579 Praha 1, Czech Republic; vojtech.turek@nm.cz• Štěpán Manda, Czech Geological Survey, Klárov 3, P.O.B. 85, 11821 Praha 1, Czech Republic; stepan.manda@geology.cz

Knowledge concerning colour patterns in fossil cephalopods has been significantly extended since publication of Treatise of Invertebrate Paleontology, Part K, in 1964 (Hoare 1978, Mapes \& Hoare 1987, Blodgett et al. 1988, Kobluk \& Mapes 1989, Mapes \& Davis 1996, Sun et al. 1999, Turek 2009 and further references therein). Nevertheless, knowledge of some aspects of colour pattern evolution and variability in ancient cephalopod molluscs are still scarce. Turek (2009, p. 492) summarised that colour patterns have been observed in 57 species of Early Palaeozoic nautiloids, which belong to 26 genera but their number is still increasing (Manda \& Turek 2009a, b). Large varieties of colour pattern types including zigzag, chevron, radial and transversal colour bands and their combinations have been described in fossil nautiloids. The majority of nautiloids displaying colour patterns come from the Silurian strata of Bohemia and Gotland, and belong to order Oncocerida. In the vast majority of species in which shell colouration is known, the colour pattern is preserved in very few specimens, sometimes even only one. In addition, colouration is usually not preserved in the entire shell. Therefore, opportunities to study intraspecific and intrageneric variation of colour pattern and its evolution and palaecological significance are quite limited.

Shell colouration in the order Discosorida (Middle Ordovician-Late Devonian) is preserved in the fossil record only rarely. Turek (1990) reported, but did not illustrate longitudinal bands in late Silurian Phragmoceras imbricatum Barrande, 1865 from Bohemia. Re-examination of the specimen (NM L 40804), however, shows presence of longitudinal and transversal colour bands on the shell surface, i.e. the same pattern as was documented by Barrande (1870, pl. 429, pp. 14-20) in oncocerid Hexameroceras panderi. During current comparative study of some cephalopod species described by Barrande (1865-1877) from the Silurian of Bohemia and subsequently reported from England and the Wales Borderland (Blake 1882), the colour pattern has been found in another specimen of P. imbricatum (Blake 1882, pl. 25, fig. 2, 2a). Surprisingly, the colour pattern in Blake's specimen differs markedly 

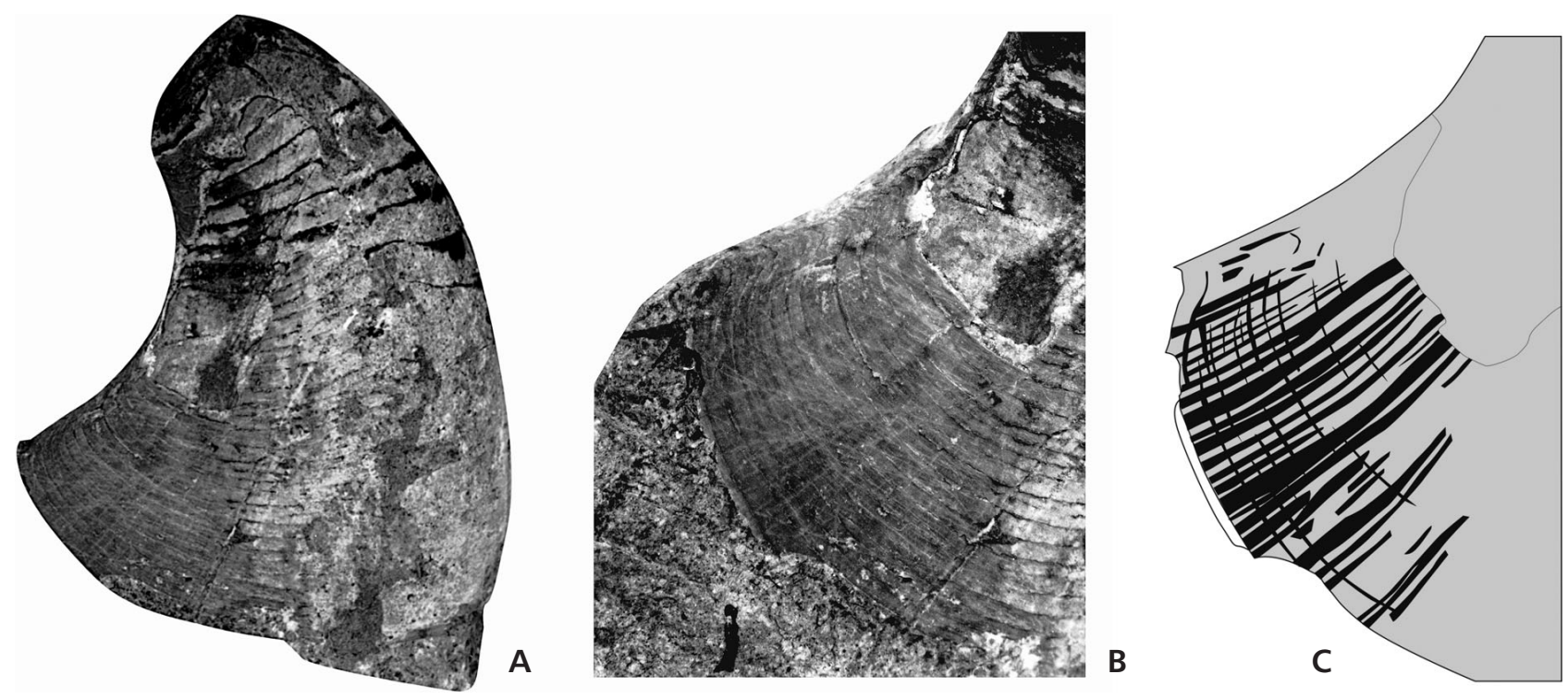

Figure 1. Phragmoceras imbricatum Barrande, 1865; NM L 40804; Ludlow, Gorstian, C. colonus Zone; Bohemia, Butovice, Na břekvici locality, Kopanina Formation; lateral view, $\times 1.7$ (A), detail of the shell with colour pattern preserved (B) and its sketch drawing $(\mathrm{C})$, both $\times 3$.

from that in the Bohemian specimen in having transverse bands running laterally, obliquely to growth lines. Examining the Silurian cephalopods from Gotland, Sweden we found several specimens of Phragmoceras with two other types of preserved colour pattern: narrow zigzags bands in $P$. eurystoma flexibile Hedström from the early Wenlock and transversal bands concordant with growth lines in $P$. dubium Hedström from the middle-late Ludlow. In contrast, irregular spots in $P$. dubium described by Foerste (1930) as original shell pigmentation (see Kobluk \& Mapes 1989) we consider to be a false colour pattern. Such a variety of colour patterns within a single species or even genus is remarkable and has not been described in any known nautiloid including present day nautilid genera Nautilus and Allonautilus.

All known specimens of Phragmoceras retaining shell colouration are described in this paper. The variation in colour pattern in this genus is considered to be the first reliable evidence of colour pattern polymorphism in nautiloids. Some others cases of striking variations of colour pattern in tarphycerids and oncocerids are discussed. The term "polymorphism in colour pattern" is used here to describe quite different types of colouration, i.e. different geometric patterns. Lesser differences in colour pattern such as width of colour bands and some irregularities occurring, for instance, in separate species of Nautilus (see Ward et al. 1977) we regard as variations.

Specimens discussed are deposited in National $\mathrm{Mu}-$ seum, Praha (prefix NM L), Oxford University Museum, (prefix OUM) and Rickmuseet, Stockholm (prefix RM). All specimens were immersed in alcohol or water before photographing.

\section{Description of colour pattern in Phragmoceras}

Four types of coloration have been found in Phragmoceras. They include 1) longitudinal bands combined with transversal bands, 2) transversal bands oblique to growth lines, 3) zigzag pattern, and 4) transversal bands concordant with growth lines. Each is described in detail below.

\section{Type A. Longitudinal bands combined with transversal bands}

This type of colouration was found in only a single specimen of Phragmoceras imbricatum Barrande, 1865 (NM L 40804, Fig. 1) from the early Ludlow, Gorstian, C. colonus Zone, Kopanina Formation from Bohemia; locality PrahaButovice, Na Břekvici (i.e. Barrande's locality Butowitz e1, for locality description see Kř́ž 1992). The specimen originates from the collection of J. Barrande. It is an incomplete, not yet fully-grown specimen with widely opened aperture preserved in dark grey biomicritic limestone; maximum dorsoventral length preserved is $56 \mathrm{~mm}$ and width about $32 \mathrm{~mm}$. The shell wall is present ventrally and laterally, on the left and right sides is deeply weathered. The ad-apical part of the body chamber is extensively damaged on the ventral side (Fig. 1).

The colour pattern is preserved in the ventrolateral portions of the body chamber. Brownish dark and hardly discernible bands sub-parallel to the axis of the shell are about 1-2 mm wide. Distance between two neighbouring strips varies markedly. Ventrolaterally dark bands cover about 40-50 percent of the shell surface. Density of bands 

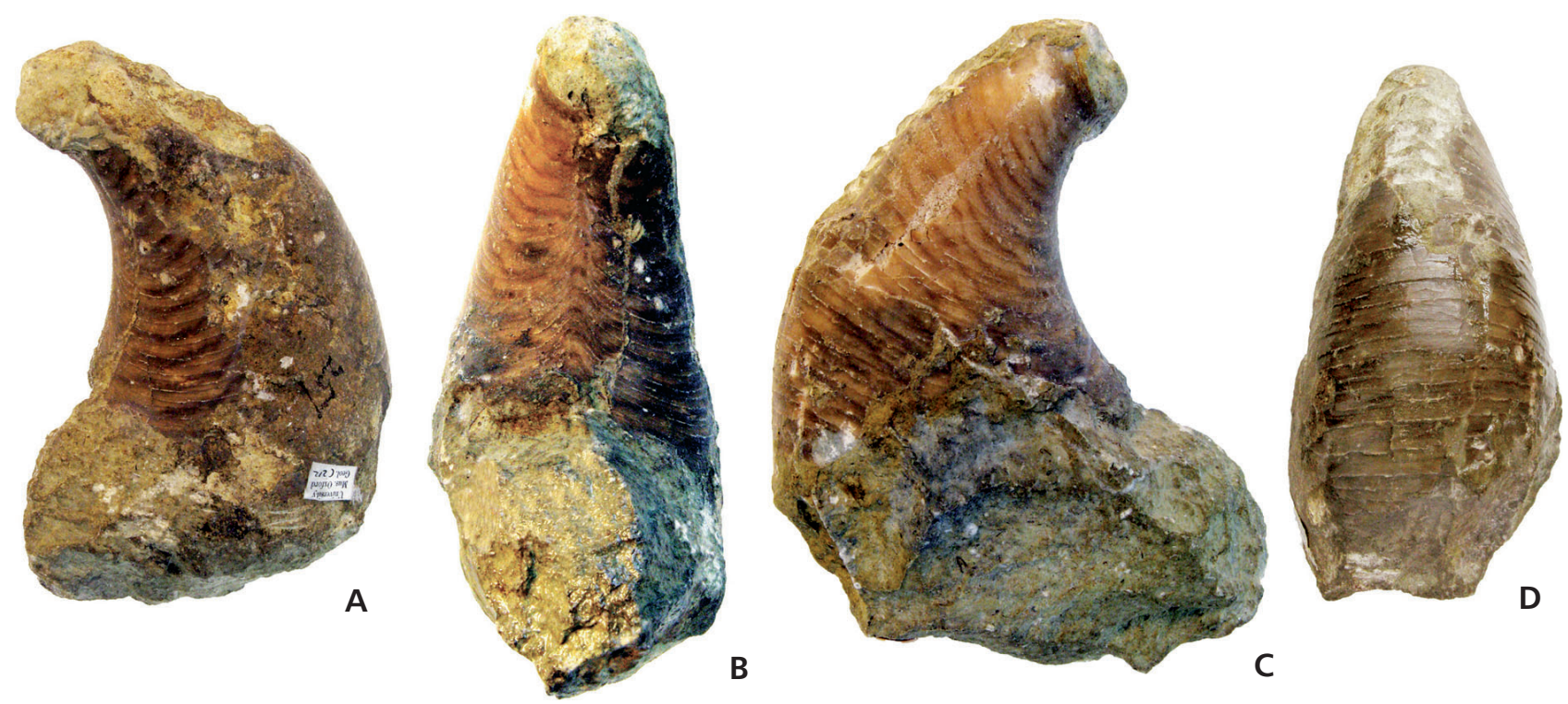

Figure 2. Phragmoceras imbricatum Barrande, 1865; OUM C 212, Ludlow, latest Wenlock; Much Wenlock Limestone; England, Ledbury; right lateral (A), ventral (B), left lateral (C) and dorsal (D) views, all $\times 0.9$.

increases laterally. It seems probable that convex side of the endogastric shell was intensively coloured but due to preservation this assumption cannot be confirmed. The longitudinal bands were combined with fine transversal and rather irregular bands to form a reticulate pattern.

\section{Type B. Transversal bands oblique to growth lines}

A specimen of Phragmoceras imbricatum, OUM C 212, from the late Wenlock, Ledbury, England, was illustrated by Blake (1882, pl. 25, figs 2, 2a) and later refigured by Holland \& Stridsberg (2004, fig. 3b, c). The specimen originates from the collection of A. Grindrod. Holland \& Stridsberg (2004) revising phragmoceratids from England reinterpreted the age of this specimen as early Ludlow. M.G. Bassett, however (written communication 2009), confirmed late Wenlockian age of this specimen as originally suggested by Blake (1882). The incomplete specimen is strongly dextrally damaged near the aperture and the apical part is missing (for detailed description see Holland \& Stridsberg 2004, pp. 306-309). Although the colour pattern is well visible, neither Blake (1882) nor Holland \& Stridsberg (2004) mentioned this feature.

The shell colour pattern can be reconstructed along the entire circumference of the shell. It is roughly bilaterally symmetrical (Fig. 2). The colour pattern has an appearance of brownish bands, contrasted by lighter interspaces. On the convex dorsal side they are sub-parallel to imbricate growth lamellae; ventrolaterally, colour bands diverge from the course of growth lamellae adaperturally at an angle of about $30^{\circ}$. Ventrolaterally, their course becomes similar to the course of growth lamellae dorsally forming an adapically-pointing tongue in the middle of ventral side. The interspaces between darker bands are markedly wider on the lateral and dorsal sides.

\section{Type C. Zigzag pattern}

Four specimens of Phragmoceras eurystoma flexibile Hedström with preserved colour pattern, which come from Silurian of Gotland, were studied. The first three specimens, RM Mo 157731, 152778-79 from the Wenlock rocks are labelled as coming from locality Visby, Norderstrand (i.e. north part of Visby Town). Slightly compressed specimens are preserved in grey marlstone; the shell was replaced by light grey calcite.

The first specimen, RM Mo 152778, is a fragment of a phragmocone damaged on the inner (ventral) side (Fig. 3A-C). Dorsoventral length is $29 \mathrm{~mm}$; width of the shell is $21.9 \mathrm{~mm}$. The colour pattern is preserved on the lateral and dorsal sides and is bilaterally symmetrical. It shows that the generally light shell was brightly coloured. Brownish zigzags resemble seismic recordings by their course. Much narrower bands with feathered edges are separated by wide, light grey interspaces. On the convex and slightly flattened dorsal side they form a very deep and narrow saddle (average angle is $30^{\circ}$ ) passing into a wide, mid-laterally situated lobe. The course of these dorsolateral as well as ventrolateral arms is complicated due to presence of smaller zigzags. Shallow and wide ventrolateral saddles traceable dextrally pass into indicated 

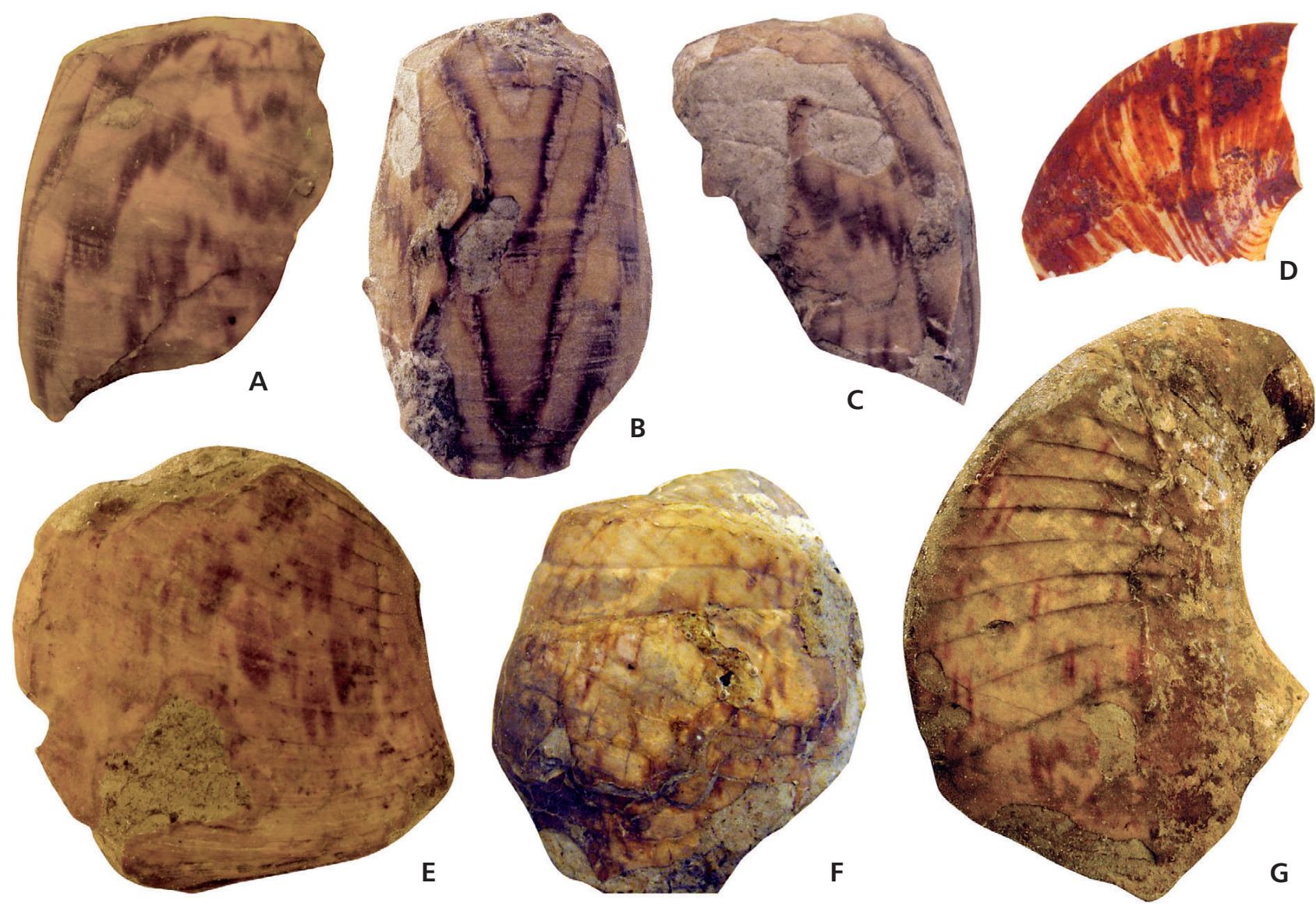

Figure 3. A-C, E-G-Phragmoceras eurystoma flexibile Hedström, 1917. Wenlock, locality Visby, Norderstrand. • A-C - specimen RM Mo 152778 , left lateral (A), dorsal (B) and right lateral (C) views, $\times 1.6$. E - specimen RM Mo 152779, lateral view, $\times 1.1 \cdot \bullet$ F - specimen RM Mo 58340, lateral view, $\times 1.1 . \bullet \mathrm{G}-$ specimen Mo 57731, lateral view, $\times 1$.2. $\bullet$ D - Phragmoceras dubium Hedström, 1917. Late Ludlow, locality Mannagärda, Gotland, specimen Mo 52087, lateral view, $\times 1.4$.

ventral lobe. The further course of bands cannot be followed due to preservation of the specimen.

The second specimen, RM Mo 152779 (Fig. 3E) is an incomplete body chamber of a fully-grown specimen showing constricted aperture. Growth lines are widely spaced. Maximum dorsoventral length is $39 \mathrm{~mm}$, width is not measurable, due to preservation. Shell with preserved colour pattern is preserved only sinistrally. Colour pattern is not so well visible in comparison with the former specimen. General character - narrow bands in form of multiple zigzags separated by wider light bands - is identical. Pigment is concentrated on some of them in the form of patches. Brownish bands disappear on the shell adaperturally so that the body chamber near the aperture seems to be primarily less pigmented than its adapical part.

The third specimen, RM Mo 57731 (Fig. 3G, a specimen figured in pl. 24 as figs 7, 8 by Hedström 1917) represents two phragmocone chambers and adapical part of the body chamber; maximal length $50 \mathrm{~mm}$, dorsoventral length $37 \mathrm{~mm}$, maximal width $22.4 \mathrm{~mm}$. Sinistrally preserved shell shows slightly indicated colour pattern of the same type as in previous specimens. Narrow bands resemble seismic recordings. The same general course of bands is also indicated.

The last specimen, RM Mo 58340 (Fig. 3F) represents a part of phragmocone and adapical part of the body chamber, cut in the medium plane. Specimen is preserved in grey limestone of Hamra beds, locality Visby, which is early Ludlow in age. Maximal dorsoventral length of shell is $67 \mathrm{~mm}$, width $43 \mathrm{~mm}$. Shell is preserved only dorsolaterally. Traces of the colour pattern form short, irregularly dispersed bands sub-parallel to the shell axis. This pattern can be derived from the previous one, but only short parts of zigzags are preserved. Whether the shell of this specimen was originally only slightly coloured or if the only slightly indicated colour pattern is a result of preservation bias is difficult to determine.

\section{Type D. Transversal bands concordant with growth lines}

Five specimens of Phragmoceras dubium Hedström, 1917 retaining original shell colouration are available for study 


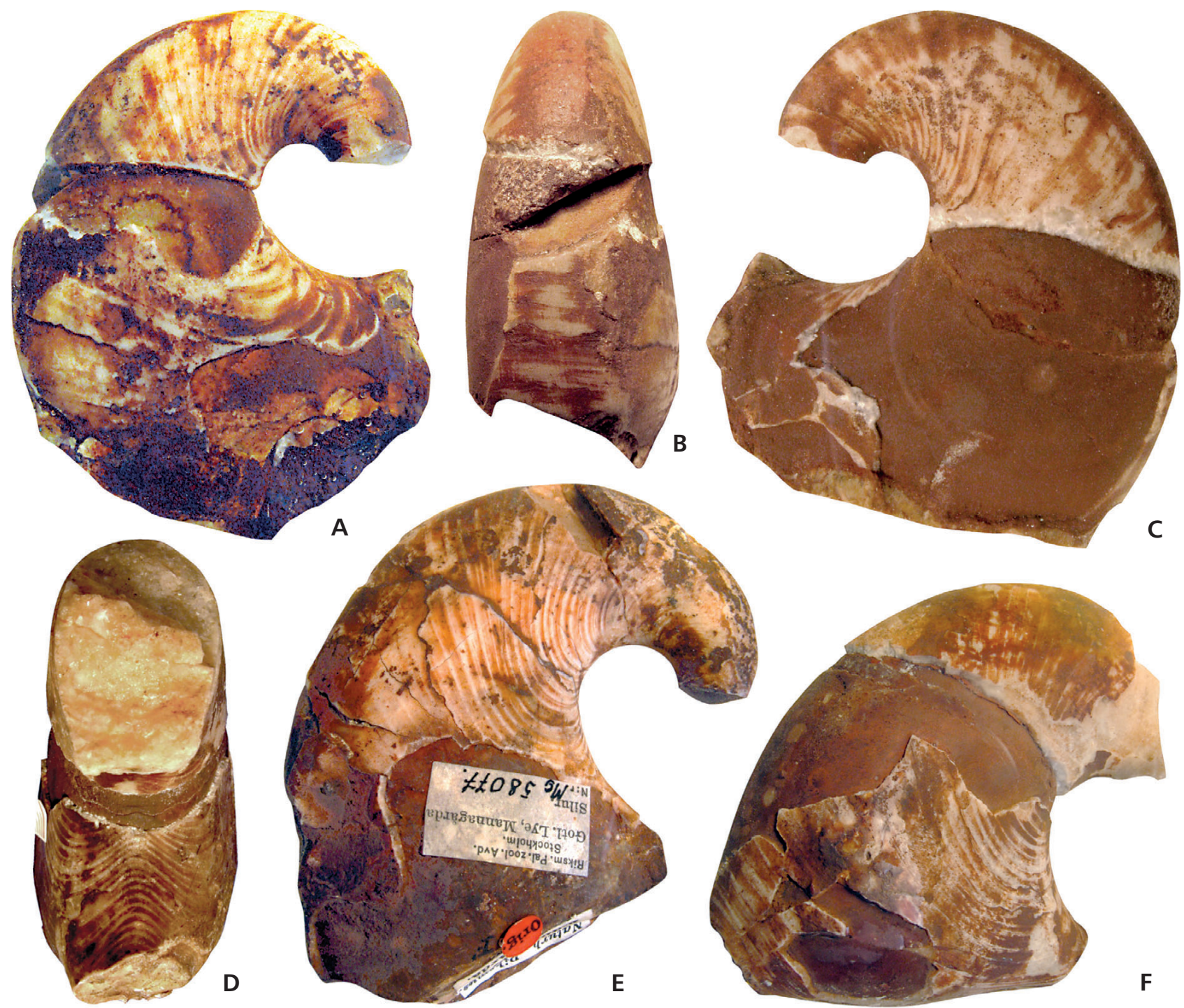

Figure 4. Phragmoceras dubium Hedström, 1917. Late Ludlow, locality Mannagärda, Gotland. • A-C - specimen Mo 58088, left lateral (A), dorsal (B) and right lateral views $(\mathrm{C}), \times 1.5$. $\bullet$ D F - specimen Mo 167633, ventral and lateral views, $\times 0.8$. $\bullet-$ specimen Mo 58077, lateral view, $\times 1.2$.

(RM Mo 52087, RM Mo 58077, RM Mo 58087-58088 and RM Mo 167633). All specimens listed above were found in locality Mannagärda, Gotland, late Ludlow in age, and are preserved in reddish fine-grained biomicritic limestone with common cephalopods.

The first specimen, Mo 58088, is an almost complete shell with open aperture, shell length is $47 \mathrm{~mm}$, width $34 \mathrm{~mm}$ (Fig. 4A-C, see also pl. 7, figs 9, 10 in Hedström 1917). Brick-red colour bands, sometimes discontinuous, run around the entire circumference of the shell, conformably with growth lines, and they also follow growth lines in the apertural region. They are almost of the same width as the light grey interspaces separating them. Marked irregularities in the course of wide bands have been observed on convex dorsal side (RM Mo 58088, Fig. 4A-C), margins of bands are sometimes feathered. Pairs of bands sometimes fused to form broader bands.

The second specimen Mo 58077 is a shell with contracted aperture and missing apical part, shell length is $56 \mathrm{~mm}$, width $46 \mathrm{~mm}$, this shell exhibits the same colour pattern as the specimen mentioned below, the width of colour bands is however slightly lower (Fig. 4E).

Similar rather narrow colour bands are shown by the third specimen - a fragment of a phragmocone, Mo 52087 (Fig. 3D).

The fourth specimen (RM Mo 167633) is a contracted body chamber with part of a phragmocone, this specimen like that described above exhibits transversal bands concordant with growth lines, the shell colouration is well visible especially on the ventral side where narrow and dense bands are developed. The margin of colour bands is sharp, 
in one case two adjacent bands are converging into one (Fig. 4D). In addition, this specimen demonstrates development of colour bands around the constricted aperture (Fig. 4F). The subdorsally positioned apertural opening surrounded with colour bands suggesting that shell growth continued in the restricted area of the hyponomic opening after formation of the hyponomic sinus.

The final specimen, Mo 58087, is a small part of a phragmocone, the colour bands are well visible on the lateral side, and they are slightly narrower than on the above mentioned specimens.

\section{Colour pattern in Phragmoceras}

Two examined shells with preserved colour pattern in Phragmoceras imbricatum show a quite different colour patterns: broad sub-transversal bands versus a combination of narrow longitudinal and transversal bands (Fig. 8). While the first type is unusual among nautiloid, the second type of colouration is almost identical with the colour pattern observed in Hexameroceras panderi (Barrande, $1865)$. Both types of pattern also differ in the ratio between pigmented and unpigmented zones. The shell in the British specimen was originally markedly lighter than the shell of the specimen coming from Bohemia.

Phragmoceras eurystoma flexibile (from Gotland) exhibits narrow zig-zag bands (Fig. 8), a pattern so far known in representatives of Oncocerida, Tarphycerida and Orthocerida. Among four fragments only one shows a constricted aperture. Zig-zags disappear in middle part of the body chamber and in this character, this species resembles adult Nautilus with an unpigmented adapertural part of the body chamber. A similar situation has been found in oncocerid Pentameroceras mirum (see below).

All specimens of Phragmoceras dubium from Gotland having broad colour bands parallel with growth lines show very similar colour patterns, but the width of colour bands and their density vary slightly. Shell colouration in $P$. dubium strongly resembles the pattern described by Stridsberg (1985, p. 24) in Octameroceras sinuosum Stridsberg, 1985 and O. rimosum (Barrande, 1865). All these specimens come from the same locality and horizon. Both Phragmoceras and Octameroceras are endogastric brevicones with contracted aperture. Intensive colouring of the convex dorsal and dorsolateral sides in Phragmoceras dubium resembles colouring of convex ventral and ventrolateral regions of the shell in extant Nautilus and Allonautilus. Furthermore, the shell colouration in Phragmoceras dubium resembles colouration observed in Cretaceous nautilid Eutrephoceras Hyatt, 1894 illustrated by Mapes \& Evans (1995) in which colour bands are subparallel with growth lines along the entire circumference of the shell. It represents a striking convergence in colour pattern development, although the living position of Phragmoceras compared to the above mentioned nautilids had to be quite different (see Manda 2008). In contrast to present-day nautilids, the fully-grown specimens of $P$. dubium also had intensively pigmented body chamber and contracted aperture.

\section{Variations of colour pattern in Early Palaeozoic nautiloids}

Barrande (1865-1877) did not observe different colouration types in any single species of Palaeozoic nautiloid. He therefore suggested very low intraspecific variability of colour pattern within this group. He examined in detail several dozens specimens of Cyrtoceras parvulum Barrande, 1866 from Ludlow of Bohemia and found only minor differences in colouration (expressed e.g. in width of colour bands). Foerste (1930) followed by later authors (e.g. Teichert 1964, Kobluk \& Mapes 1989, Turek 2009) concluded that the colour pattern is usually a species-specific or even genus-specific feature in Early Palaeozoic nautiloids. Colour pattern polymorphism described in Phragmoceras herein is exceptional; some remarkable variations in colour pattern observed in Silurian nautiloids are discussed below.

\section{Peismoceras pulchrum (Barrande, 1865) from Bohemia}

An interesting variation in colour pattern has been documented in the Silurian lechritrochoceratid Peismoceras pulchrum from the early Ludlow (Gorstian) strata of Bohemia (Turek \& Manda 2010). While some specimens show spiral bands on one lateral side and a zigzag-pattern on the opposite side of the shell, the majority display zigzags throughout the entire circumference of the shell. The passing of one type into the second one demonstrates that one pattern is derived from the other (Fig. 5).

\section{Pentameroceras mirum (Barrande, 1865) from Gotland}

Stridsberg (1985, fig. 25C, RM Mo 154005) illustrated a specimen assigned to this species, which display fine brownish, but very unequally developed transversal bands concordant with the growth lines. He interpreted these bands, resembling coloration in Octameroceras Hyatt, 1900, as colour patterns. However, these narrow bands in the shell seem quite likely to be a false colour pattern caused by diagenetic processes, and for that reason the authors of this paper do not consider this to be a true example 

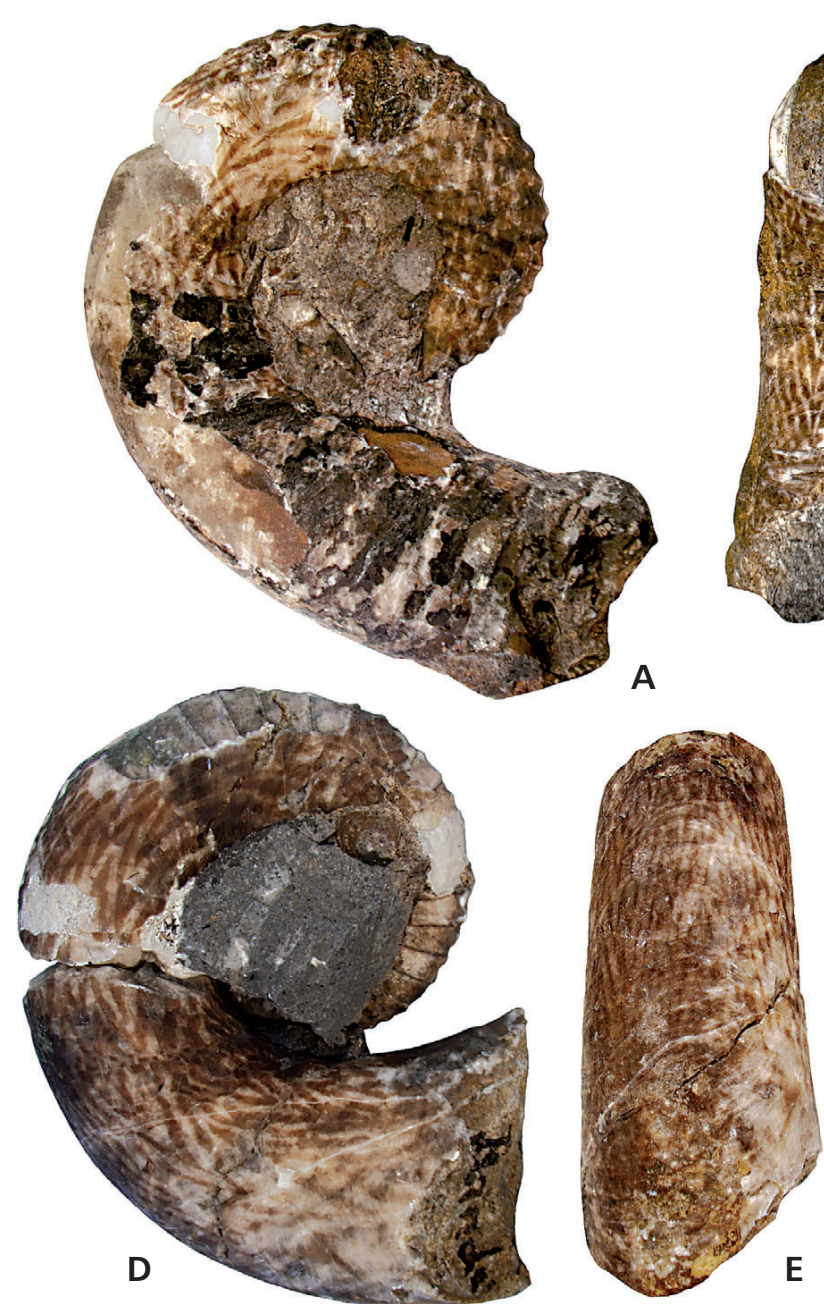

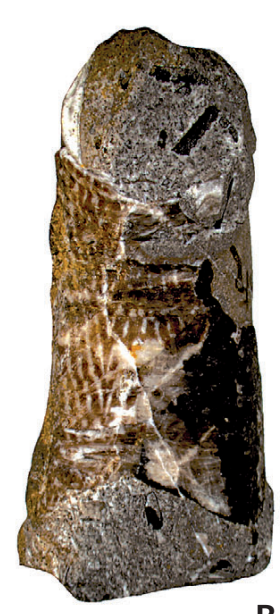

B
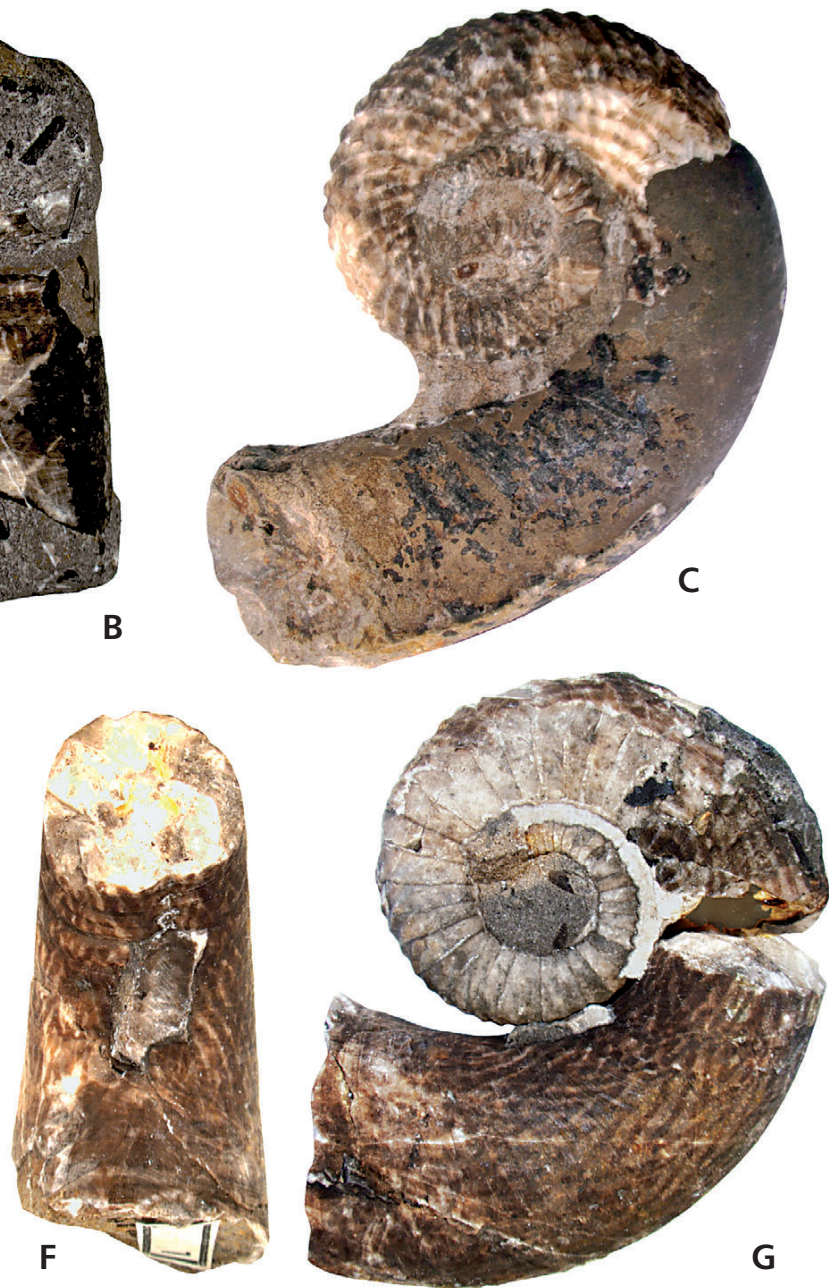

Figure 5. Shell colouration in the coiled barrandeocerid Peismoceras pulchrum (Barrande, 1865), Ludlow, early Gorstian, locality Butovice Na břekvici, Kopanina Formation, Bohemia. • A, C - specimen NM L 8055, right lateral (A) and left lateral (C) views, × 1.4. • B - specimen NM L 27401, body chamber, dorsal view, $\times 1.8 . \bullet \mathrm{D}-\mathrm{F}-$ specimen NM L 27400, right lateral (D), ventral (E), dorsal $(\mathrm{F})$, and left lateral $(\mathrm{H})$ views, $\times 1.4$.

of colour pattern polymorphism. For a more detailed discussion of false colour pattern see Mapes \& Davis (1996) and Klug at al. (2007).

In examining $P$. mirum from Gotland, we have found three specimens with very well developed chevron patterns. The best-preserved specimen (RM Mo152778, Fig. 6C-F) is a body chamber and part of a phragmocone. The aperture is contracted with characteristic five narrow lobes; maximum shell length preserved is $17 \mathrm{~mm}$, diameter $11 \mathrm{~mm}$. Information about the locality is missing, but the mode of preservation indicates that the specimen comes from locality Mannagärda (Ludlow in age). The specimen shows three well visible chevron colour bands, the fourth is preserved only in part. The bands are narrow and separated by a broad, unpigmented zone. The last chevron band is less intense than the others. The colour bands are restricted to the phragmocone and base of the body chamber; part of the body chamber close to the aperture is uncoloured, except for a darker grey band running around the aperture. As the specimen represents a mature individual, this band may be equivalent of black band deposited in the apertural region of mature specimens (comp. Ward 1987).

Two other specimens of $P$. mirum (RM Mo154295 and RM Mo154297) are preserved in grey argillite mudstone of Halla beds, locality Hörsne kanal, late Wenlock, Homerian, Wenlock. The first specimen (RM Mo154297, Fig. 6A) is a phragmocone with a preserved base of the body chamber, maximum length is $21 \mathrm{~mm}$, and diameter increases from 5 to $15 \mathrm{~mm}$. The shell is preserved in lateral sides. The shell wall is dark grey in colour. Four light-grey narrow bands are visible. The first and most apical band (width $0.5 \mathrm{~mm}$ ) is straight. The next three bands are chevron-like and their amplitude and width (from 0.5 to $1 \mathrm{~mm}$ ) increases toward the aperture. The last band occurs at the base of the body chamber. The second specimen (RM Mo 154295, Fig. 6B) is a fragment of a phragmocone and body chamber, length $20 \mathrm{~mm}$ and diameter $13 \mathrm{~mm}$. The shell is dark-grey with one partly preserved, narrow, white zig-zag stripe. 

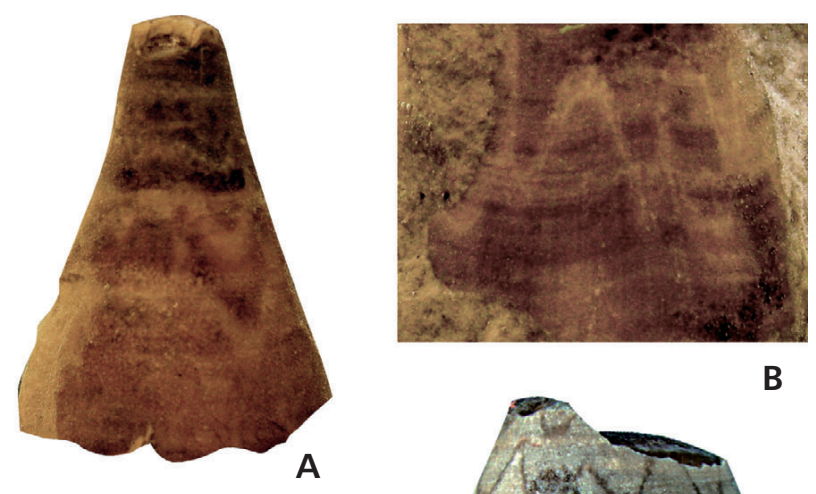

B
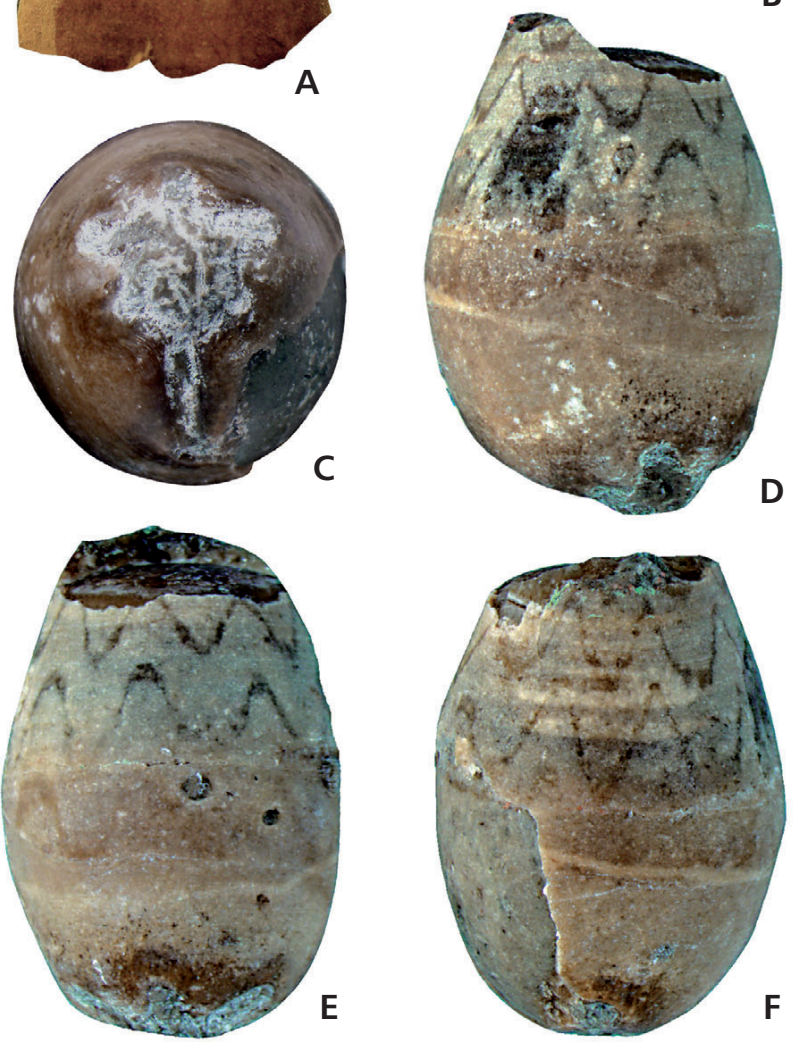

Figure 6. Shell colouration in the Silurian oncocerid Pentameroceras mirum (Barrande, 1865) from the Silurian rocks of Gotland. • A - specimen Mo 154297, late Wenlock, Homerian, Wenlock, Halla beds, locality Hörsne kanal, lateral view, × 1.8. • B - specimen Mo 154295, late Wenlock, Homerian, Wenlock, Halla beds, locality Hörsne kanal, detail of phragmocone, ventral view, $\times 2.5$. $・ \mathrm{C}-\mathrm{F}-\mathrm{RM}$ Mo 152778, late Ludlow, locality Mannagärda, Gotland, apertural (C), lateral (D), dorsal (E) and ventral $(\mathrm{F})$ views, $\times 2.6$.

The described variability of the colour pattern in oncocerid Pentameroceras mirum from Gotland expressed in intensity of colouration is not interpreted as a case of colour pattern polymorphism as the pattern is the same (Figs 6A-F, 8).

\section{Hemiphragmoceratidae Foerste, 1926 from Gotland and Bohemia}

The Hemiphragmoceratidae Foerste, 1926 group brevicone oncocerids with a slightly curved endogastric shell and thick subcentral siphuncle (e.g. Stridsberg 1985). Species of this family described by J. Barrande were originally placed in the genus Phragmoceras. Barrande (1870, pl. 429, figs 14-20) illustrated three specimens of Hexameroceras panderi (Barrande, 1865) from the late Ludlow of Bohemia in which the coloration is characterised by a combination of narrow longitudinal and transversal bands. The same colour pattern has been observed in several other specimens by the present authors. The variation in colour pattern is expressed in the density of longitudinal bands and their width, which is always lower than that of the interspaces between the bands (Fig. 5C-E). In addition, a specimen of Tetrameroceras sp. from latest Ludlow of Bohemia exhibits a quite similar shell colouration (unpublished data).

Stridsberg (1985, fig. 25B) illustrated the colour pattern in Octameroceras rimosum (Barrande, 1865) from Ludlow of Gotland. Distinct colour bands follow the growth lines and the longitudinal bands are not present. However, an interesting anomaly of colour pattern is visible on the dorsal (convex) side of the slightly endogastrically curved shell of $O$. rimosum. In a specimen illustrated by Stridsberg (1985, fig. 25B, RM Mo 56302), several transversal colour bands on the dorsal side of the phragmocone are disrupted (Fig. 7B). The colour pattern in this part of the shell consists of discontinuous longitudinal bands, similar to Bohemian Hexameroceras panderi (Fig. 7C-E).

\section{Variability of colour pattern in nautiloids}

Data concerning colour patterns in Tarphycerida, except for Peismoceras mentioned above, are so scarce that tracing the variation in colour patterns between individual genera is impossible. Nevertheless, narrow zigzag colour bands occurring in Peismoceras are known in some other nautiloids (oncocerids and discosorids) as well as in orthocerids (e.g. Foerste 1930, Turek \& Manda 2010). The oldest known colouration in the Middle Ordovician nautiloid Hoedstromoceras Foerste, 1930 of uncertain position (Foerste 1930) has a similar character.

Three specimens of Pentameroceras mirum (Fig. 8) show similar colour patterns characterised by chevron bands. Nevertheless, there are distinct differences in their arrangement. A specimen from Mannagärda shows narrow pigmented bands; in contrast, two specimens from Hörsne kanal exhibit broad pigmented bands separated by narrow, unpigmented zones. It is a remarkable variability in colouration, but the type of the pattern is the same. It is hard to identify what might have influenced this variability. The differences in the environment may be one of the explanations. Pentameroceras with narrow pigmented bands comes from the Mannagärda locality which is situated on a shallow platform, while Pentameroceras from the Hörsne 
kanal locality inhabited the distal platform margin. The correlation between depth (i.e. off-inshore facies) and intensity of pigmentation needs to be checked in other nautiloids.

A similar colour pattern as has been observed in Pentameroceras is known in some other breviconic rizosceratids from the Silurian of Bohemia, especially Cyrtoceras parvulum Barrande, 1866 having broad, pigmented chevron bands (Barrande 1865-1877, Ruedemann 1921, Foerste 1930, Teichert 1964). Rizosceratidae and Trimeroceratidae are closely related families comprising short breviconic (straight or slightly curved) shells with thin ventral or sub-ventral empty siphuncle, but in the Trimeroceratidae the aperture is contracted (Sweet 1964, Stridsberg 1985). There is also striking similarity in the ontogenetic development of colour pattern. Cyrtoceras parvulum and Pentameroceras mirum from Hörsne kanal shared broad, pigmented bands separated by narrow, unpigmented (light) zones. The first unpigmented zone in the apical part of the shell is straight, others zones pass rapidly in chevron-like zones, in which their width and amplitude increases. Early shells of Nautilus exhibits coloration quite similar to latter growth stages, even before hatching time (see Stenzel 1964, fig. 64).

Hexameroceras and Octameroceras (Fig. 7) are closely related genera, as noted already by Stridsberg (1985), and they differ in the shape of contracted aperture in fullygrown specimens. Sweet (1964) even considered both genera congeneric. Hexameroceras from Bohemia exhibits a reticulate pattern consisting of a combination of narrow, transversal and longitudinal bands. Octameroceras from Gotland shows colour bands running parallel with growth lines. Nevertheless, on the ventral side is a zone in which narrow, longitudinal bands (as in Hexameroceras) are present. A similar pattern has been locally observed in present day Nautilus pompilius, in which similar anomalies appear just after repairing shell damage. This anomaly further confirms natural condition of colouration in Octameroceras from Gotland.

By analysing these cases, we can conclude that there existed remarkable variability in colour pattern in some early Palaeozoic nautiloids; other clear evidence of polymorphism, besides Phragmoceras, in species-genera level have not been found.

Figure 7. Colour pattern in the Silurian nautiloids of the family Hemiphragmoceratidae (Oncocerida). • A, B - Octameroceras rimosum (Barrande, 1865), RM Mo 56302, late Ludlow, locality Mannagärda, Gotland, ventral (A) and dorsal (B) views, $\times 2$. $\bullet$ C-E - Hexameroceras panderi (Barrande, 1865), Ludlow, latest Ludfordian, locality Velká Chuchle, Bohemia; C, NM L 21205; specimen illustrated by J. Barrande (1870, pl. 429, fig. 16), lateral view, $\times 1$; D, E - NM L 21306; specimen illustrated by J. Barrande (1870, pl. 429, figs 19, 20), Bohemia, dorsal (D) and lateral (E) views, $\times 0.7$.
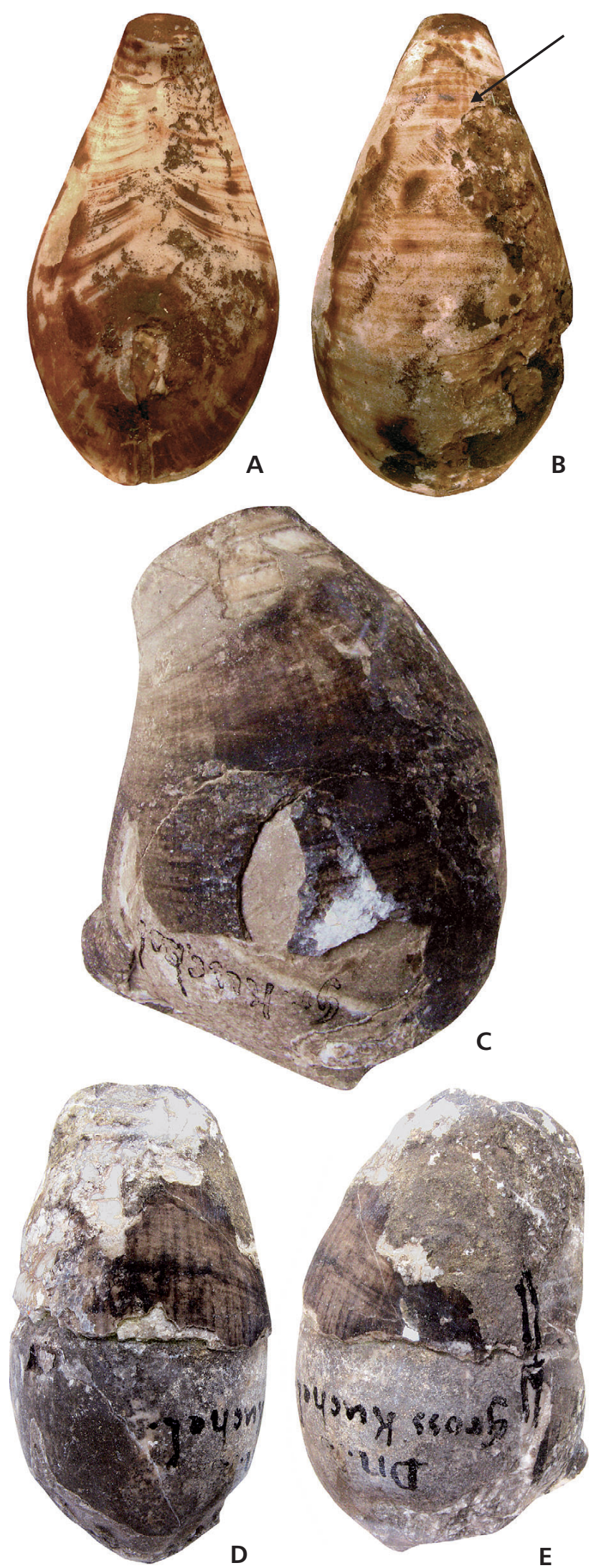

E 


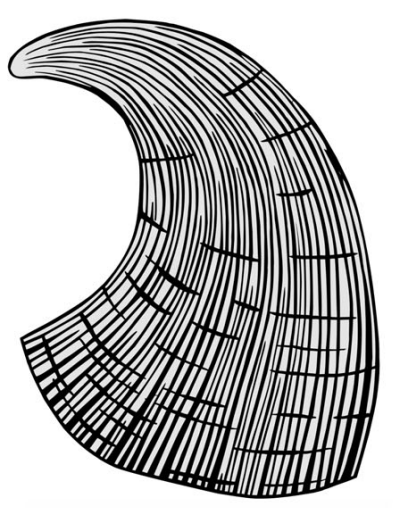

Phragmoceras imbricatum (Bohemia)

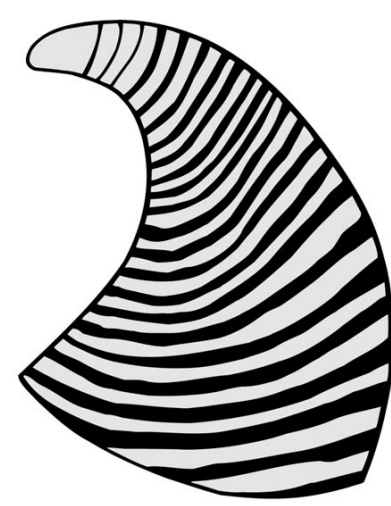

Phragmoceras imbricatum (Wales)
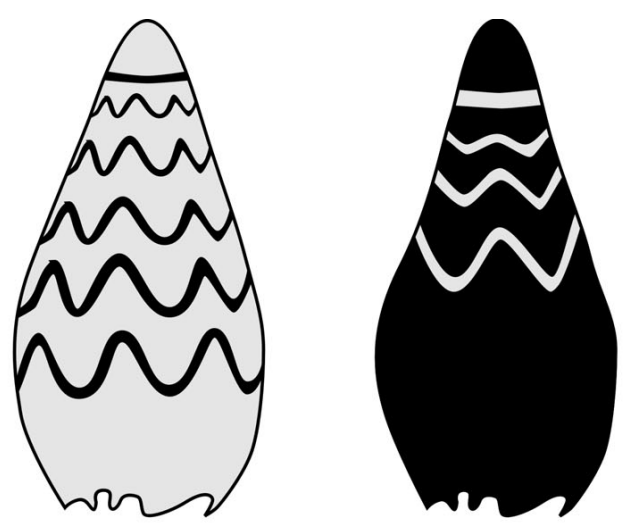

Pentameroceras mirum

(Gotland)

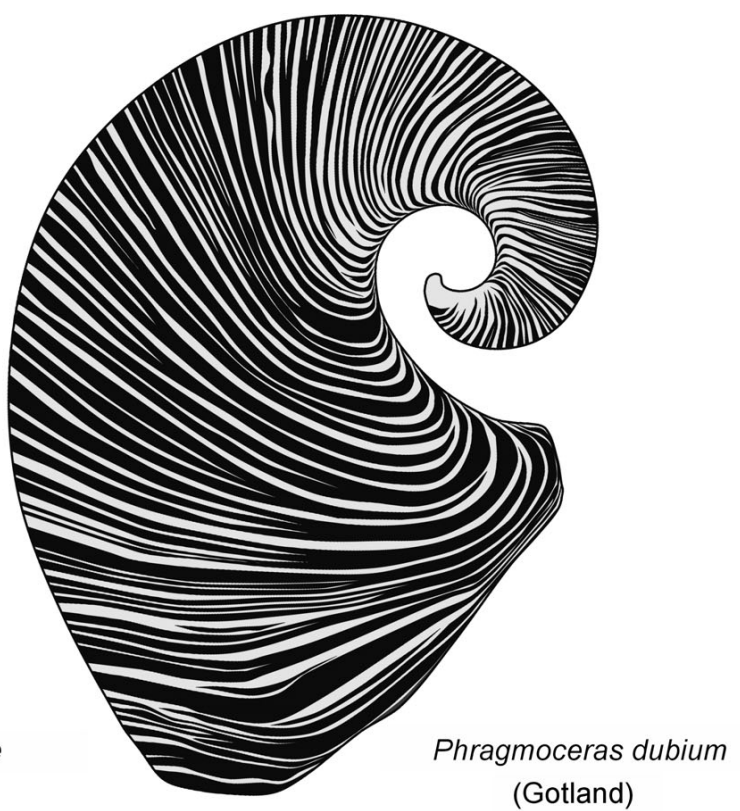

(Gotland)

(Gotland)

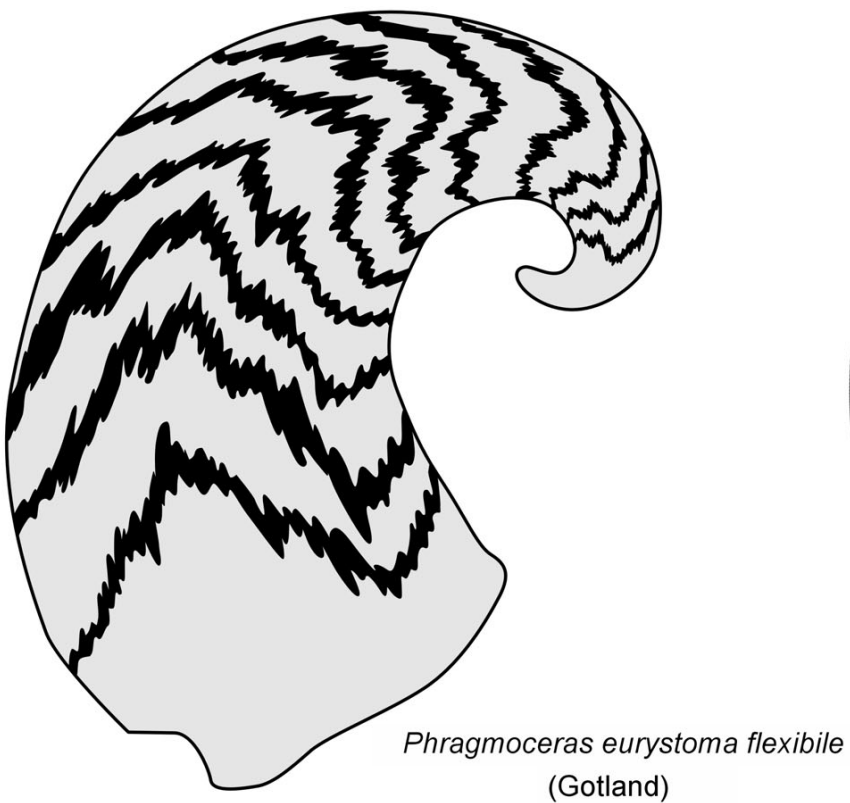

Figure 8. Schematic reconstruction of coloured shells of Phragmoceras (Phragmoceras imbricatum Barrande, 1865, Phragmoceras eurystoma flexibile Hedström, 1917, Phragmoceras dubium Hedström, 1917) and Pentameroceras mirum (Barrande, 1865). Not in scale.

\section{Discussion}

Ward et al. (1977) briefly described a variety of colour patterns in Nautilus pompilius and N. repertus. They mentioned two types of colour pattern in these species - a group showing brown stripes extending from the venter to umbilicus (typical for $N$. pompilius) and another group showing a brown patch on the umbilicus and strips extending from the venter to the middle of the lateral sides - a pattern characteristic for $N$. repertus. They also found a few transitional patterns between both variants. They have not found any correlation of these patterns with sex or depth. Despite this fact, shell colouration has been used as species or subspecies-distinctive feature (Habe \& Okutani 1988, Saunders 1987). The general character of colour patterns in Nautilus species, however, is the same - transversal bands ventrally and ventrolaterally concordant with growth lines, sometimes with pairs of bands fused to form broader bands. Laterally, bands are sometimes bifurcating, running obliquely to growth lines. Two known species of Allonautilus exhibit ventrolaterally largely non-bifurcating colour bands coalescing across the venter, disappearing on the shoulder (Ward \& Saunders 1997). The common feature of all fully mature specimens of living nautilids is white body chamber except the area near the umbilicus (e.g. Ward 1987).

Despite the fact that patterns of shell colour display a large diversity in Palaeozoic nautiloids and orthoceratoids, none of them show a colour pattern identical with the pattern characterising Recent Nautilus or Allonautilus (see Kobluk \& Mapes 1989). Functions of colour pattern in fossil invertebrates have been widely discussed (see the references in Mapes \& Davis 1996, 
Mapes \& Schneck 1987). These authors summarized opinions concerning potential function of colour patterns. The shell colouration can be related to metabolism, vision, shell strength, light screening, thermoregulation or alternatively, according to Bauchau (2001) may be associated with the regulation of the growth of the shell to achieve developmental stability. As in Recent Nautilus (see Stenzel 1964, Cowen et al. 1973, Westermann 1998), colour patterns in fossil nautiloids disrupted the outline of the animal and served as a camouflage and thus as protection against predators. Such a function also seems to be most probable for Silurian Phragmoceras. Reliable explanation of remarkable colour polymorphism in Phragmoceras is, however, difficult. The number of specimens with preserved colour pattern is still very low. Precise data dealing with occurrence and stratigraphic level of British and some Swedish specimens are not available in necessary detail.

Colour pattern polymorphism in Phragmoceras can be connected with the temporary isolation of small populations, differences in latitude reflected in temperature of water, and perhaps depth and lighting of the inhabited environment. Despite some discrepancies in autecological interpretation of Phragmoceras among cephalopod students, all phragmoceratid species are morphologically very similar and consequently they probably have similar modes of life. However, Phragmoceras occurs in different facies and thus its adaptive potential was relatively high.

What really triggered colour polymorphism in Phragmoceras? Possible causes are given below. All other known cephalopods which possessing the same colour pattern as Phragmoceras and co-occurring with Phragmoceras are considered in discussion below.

\section{Colour pattern versus depth inhabited}

Depth inhabited may be an important agent of colour pattern development. It is important to emphasize that no colour polymorphism at the species-genus level has been found in one locality. All Silurian nautiloids inhabited relatively shallow water environment, not exceeding 150-200 m (Westermann 1998). Table 1 shows the distribution of colour pattern when compared to the depth zone. Shallow and deeper water settings are distinguished based on facies; shallow means light coloured limestones, grain-packstones, with highly diversified benthos and very rare pelagic elements; deeper facies comprise grey limestones, mostly wackestones, containing more pelagic elements and moderately diversified benthos.

It appears that only two colour patterns may be connected with depth zone: transversal-longitudinal narrow bands and bands parallel with growth lines. It is interesting
Table 1. Colour pattern correlation with palaeogeographical setting and water depth at Silurian Phragmoceras and other nautiloids.

\begin{tabular}{|c|c|c|c|}
\hline \multirow[b]{2}{*}{ Colour pattern } & \multirow{2}{*}{$\begin{array}{c}\text { Temperate } \\
\text { Bohemia }\end{array}$} & \multicolumn{2}{|c|}{ Tropical } \\
\hline & & England & Gotland \\
\hline \multicolumn{4}{|l|}{ Phragmoceras } \\
\hline $\begin{array}{l}\text { Bands sub-parallel with } \\
\text { growth lines }\end{array}$ & 0 & shallow & 0 \\
\hline $\begin{array}{l}\text { Bands parallel with growth } \\
\text { lines }\end{array}$ & 0 & 0 & shallow \\
\hline $\begin{array}{l}\text { Transversal-longitudinal } \\
\text { narrow bands }\end{array}$ & deeper & 0 & 0 \\
\hline Zig-zags & 0 & 0 & deeper \\
\hline \multicolumn{4}{|l|}{ Silurian nautiloids in generally } \\
\hline $\begin{array}{l}\text { Bands sub-parallel with } \\
\text { growth lines }\end{array}$ & shallow-deeper & shallow & 0 \\
\hline $\begin{array}{l}\text { Bands parallel with growth } \\
\text { lines }\end{array}$ & 0 & 0 & shallow \\
\hline $\begin{array}{l}\text { Transversal-longitudinal } \\
\text { narrow bands }\end{array}$ & deeper & 0 & 0 \\
\hline Zig-zags & shallow-deeper & 0 & deeper \\
\hline Longitudinal bands & shallow-deeper & 0 & 0 \\
\hline Undulating lines & shallow-deeper & 0 & 0 \\
\hline Chevron pattern & shallow-deeper & 0 & shallow-deeper \\
\hline
\end{tabular}

that both patterns duplicate each other in phyletic lines. Phragmoceras imbricatum and Hexameroceras mirum from Bohemia shows transversal-longitudinal narrow bands. Phragmoceras dubium and Ocameroceras sinuosum and O. rimosum (Octameroceras is close related with Hexameroceras) from the Managarde locality exhibit bands parallel with growth lines.

Another probably depth related feature is represented by the ratio between pigmented (darker) and unpigmented (lighter) zones. Rather darker coloured shells occur in deeper water settings, it also seems valid in Phragmoceras. An interesting example is Pentameroceras, described above. Specimens from shallow water settings shows narrow coloured bands while specimens from deeper water mudstones exhibit broad pigmented bands, however, the colour pattern is the same (Fig. 9). It means that not only colour pattern polymorphism, but also proportion between parts of the pattern may the change visual characters of the shell.

Balinski (2010) summarised that marine invertebrates with colour-patterned shells essentially inhabit shallow water depths not exceeding $200 \mathrm{~m}$. It represents an important fact in the reconstruction of depositional environment and palaecology because there is discussion about the bathymetric condition of some ancient biofacies. Coloured nautiloids from the Silurian cephalopod limestone biofacies in Bohemia thus may indicate a lower depth limit for this facies (see discussion in Miller \& Furnish 1937 and Ferretti \& Kříž 1995). 


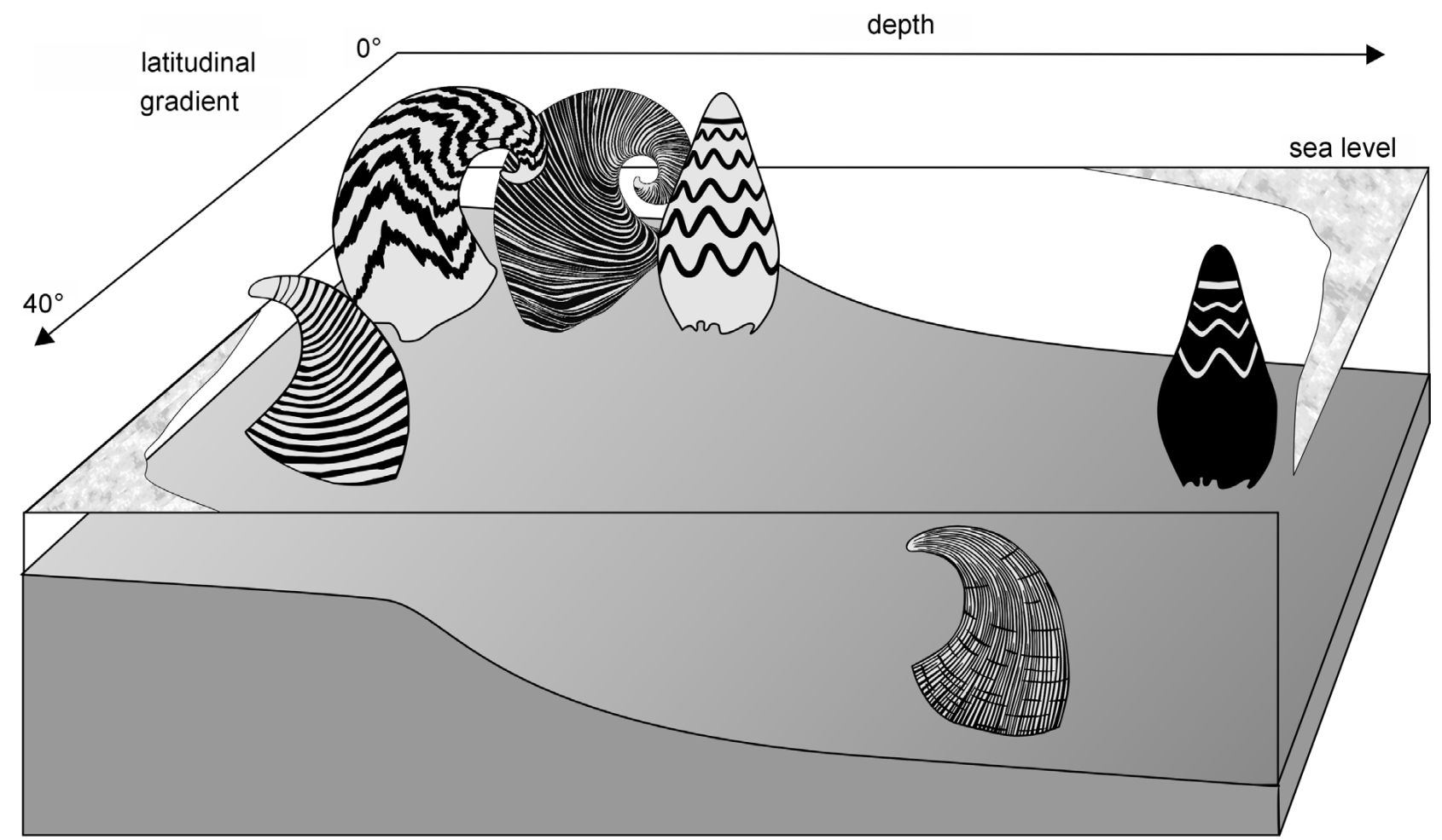

Figure 9. Colour pattern in the Silurian nautiloids Phragmoceras and Pentameroceras in relation to the depth and latitudinal position. Nautiloids inhabiting shallow water settings display rather lighter coloured shells in comparison with those that inhabited deeper water settings.

\section{Colour pattern as a morphotype-specific feature?}

The link between morphotype and colour pattern is still poorly understood, but a correlation between them sounds reasonable if the shell colouration functioned as a camouflage in nautiloids. Convergences in morphotype are common in Palaeozoic nautiloids (e.g. Manda \& Turek 2009a) and may coincide with convergence in colour patterns (Manda \& Turek 2009b). All Phragmoceras species shared similar shells. Some differences in shell flexure and shape of aperture probably affected the mode of life only slightly (Manda 2007, 2008; Manda \& Frýda 2010). It suggests that in this case the colour pattern polymorphism is not related to morphotype and shell shape.

\section{Colour pattern polymorphism as anti-predatory feature?}

Shell shape and sculpture play an important role in buoyancy control and swimming quality (velocity, drag). Sculpture serves also a protective function against predators (Vermeij 1987). The colour pattern may be an analogous important agent in camouflage in both predator and prey (Kobluk \& Mapes 1989, Cowen et al. 1973). Ordovician and Devonian cephalopods with preserved colour pattern are very rare. Consequently, evaluation of the possible trends in colour pattern evolution is still impossible, although remains as a promising task for future study, e.g., of colour polymorphism in relation to diversity of predators. Nevertheless, all known types of colour patterns appeared at least by Silurian time, i.e. before the radiation of crushing predators in the Devonian (Signor \& Brett 1984).

\section{Fabrication noise, exaptation and shell coloration}

Gould \& Lewontin (1979) suggested that not all morphological features need an adaptive explanation. Many modern molluscs exhibits complicated colour patterns, although shell colouration is not visible during the life of an animal due to infaunal burrowing or covering of the shell by algae or epifauna. However, in cephalopods such as Nautilus, shell colouration is visible during life and thus influences the life of the animal. It is possible, that primary deposition of pigments in the shell served a different function (e.g. metabolic waste), and thus, the protective function of colouration represents in fact exaptation.

Boettiger et al. (2009) suggested that colour patterns in aquatic molluscs are a neurosecretory phenomenon and connected colour pattern with a neural model. They concluded that similar species could exhibit significantly different 
patterns, which means that the pattern differences cannot be the result of dramatic anatomical differences. According to Boettinger et al. (2009), pigmentation pattern may be change as a result of environmental disruptions. Shell colouration in Phragmoceras supports this explanation. However, it seems that specimens of species from populations inhabiting similar environment exhibit similar shell colouration. It supports assumption that the colour pattern functioned as camouflage in nautiloids, and thus, may be under selective control. Boettiger et al. (2009) also pointed out that colour patterns commonly degenerated during shell growth into a uniform pattern. It is not true in nautiloids, the pattern is archived during the entire life and even the apertural region of the shell may be unpigmented in fully-grown shells. It further supports the view that shell colouration functioned as an exaptation feature.

Evaluating the colour pattern polymporphism it should be taken in account that the effect of screening of a longitudinally banded shell and a shell with a combination of longitudinal and transversal bands would be probably the same in the photic zone as the effect of a transversally coloured shell. Nevertheless, the quality of vision of Silurian predators is unknown, future experiments with present day Nautilus may help there.

\section{Shell coloration as a taxa specific feature?}

In general, there exists correlation between colour pattern character and taxon in molluscs. Colour pattern in living gastropods is commonly species-specific and helps very much in specific recognition (Cox 1960). Concerning recent bivalves, Cox \& Nuttall in Cox (1969) stated that certain types of colour patterns, or even the absence of coloration can be characteristic of particular families and genera, and may be extremely constant within a species. The latter authors, however, mentioned that many exceptions exist. In contrast with extant nautilids, some Recent molluscs, especially gastropods and bivalves exhibit remarkable polymorphism in colour pattern, expressed in quite different types of coloration (see Clarke 1978, Hoagland 1977, Reimchen 1978, Cook 1998). Within one species of some bivalves and gastropods there are present, e.g., spots of many shapes and sizes, zigzag bands, and spiral stripes. Striking intrageneric and intraspecific colour pattern polymorphism ascertained in the Silurian discosorid Phragmoceras is reported in nautiloids for the first time. The cause of colour polymorphism may be an effect of taxonomic grouping. The specimens of Phragmoceras imbricatum would not really belong to the same species, and Phragmoceras including more than sixty species should be a cumulative genus. However, there is general agreement shared by many authors against this explanation.

\section{Conclusions}

Colour patterns are frequently supposed to be a species- or even genus-specific/diagnostic feature in ancient nautiloids. Present day Nautilus and Allonautilus are not exceptions (e.g. Foerste 1930, Kobluk \& Mapes 1989, Turek 2009). However, colour pattern polymorphism has been documented in gastropods and bivalve molluscs. The first incontrovertible evidence for polymorphism in nautiloids is in Silurian Phragmoceras. Four different types of colour patterns on shells reflecting different mode of deposition of pigment by mantle margin have been found in this genus; two of these types even occur in a single species Phragmoceras imbricatum.

It is assumed that all species of Phragmoceras inhabited the photic zone and had a similar mode of life. Whether they were nectobenthic or rather active swimmers is not quite clear, but their body chamber, owing to the position of the centre of gravity of the animal, had to be situated almost vertically (Barskov 1989, Westermann 1998, Holland \& Stridsberg 2004, Manda 2008). Shells of all specimens of Phragmoceras with preserved colour pattern are very similar in shell morphology; but they were found in different limestone facies and palaeogeographic position. No colour polymorphism was observed in shells from one locality. The primary function of the pigmentation pattern, however, is still subject to discussion (references see in Mapes \& Davis 1986, Bauchau 2001). If it served as a form of crypsis, e.g. an effective strategy to avoid predation, then quite different types of colouration in Phragmoceras may indicate different solutions to this problem. Colour polymorphism may be related to depth zone, rather than latitudinal position. Differences in colouration probably also reflect distribution pattern of phragmoceratids with isolated local populations through time.

No other example of colour polymorphism in species-genus level was found, although distinct variability in colour patterns has been found in Silurian nautiloids Pentameroceras and Peismoceras. The relation between primarily pigmented and unpigmented areas occupying the surface of the shell varies among species and it may be influenced by depth inhabited (visually darker versus lighter shell). The partly unpigmented part of the body chamber - a feature clearly characterising Recent Nautilus or Allonautilus, is documented for the first time in fossil nautiloids in Phragmoceras dubium erystoma and Pentameroceras.

\section{Acknowledgements}

The research was supported by projects of the Czech Grant Agency, 205/09/0260 (VT), 205/09/0703 (ك̌M), and Ministry of Culture project DE06P04OMG009 (VT). The author thanks Derek Siveter and Eliza Howlett (Oxford University Museum, 
England), Jan Bergström, Christine Franzen and Jonas Hagström (Ricksmuseet Stockholm, Sweden) for access to the collection and their kind assistance during our stay in institutions mentioned, Radvan Horný (National Museum, Prague, Czech Republic) for critical reading of the manuscript, Petr Daneš (Prague, Czech Republic) for improving English, reviewers comments by Andrzej Baliński (Instytut Paleobiologii PAN, Warszawa, Poland) and Robert B. Blodgett (US Geological Survey, Anchorage, Alaska) were very important for the final form of the manuscript. Jan Sklenář (National Museum, Prague, Czech Republic) kindly made a reconstruction of Phragmoceras dubium.

\section{References}

BALIŃSKI, A. 2010. First colour-patterned strophomenide brachiopod from the earliest Devonian of Podolia, Ukraine. Acta Palaeontologica Polonica 55, 695-700.

BAUCHAU, V. 2001. Developmental stability as the primary function of the pigmentation patterns in bivalve shells? Belgian Journal of Zoology 131, 23-28.

BARRANDE, J. 1865-1877. Systême silurien du Centre de la Bohême, I. ère partie: Recherches Paléontologiques, vol. II, Céphalopodes. 1865, pls 1-107; 1866, pls 108-244; 1867, 712 pp.; 1868, pls 245-350; 1870, pls 351-460; 1870, 266 pp.; 1874, 804 pp.; 1877, 1505 pp.; 1877, supplement, pls 461-544; 1877 supplement, 297 pp. Self-published, Prague \& Paris.

BARSKOV, I.S. 1989. Morfogenez i ekogenez paleozojskich cefalopod. 160 pp. Izdatelstvo Moskovskogo Universiteta, Moskva. [in Russian]

BLAKE, J.F. 1882. A monograph of the British fossil Cephalopoda. Part I. Introduction and Silurian species. 248 pp., 31 pls. London.

Blodgett, R.B., Boucot, A.J. \& Koch, W.F. II 1988. New occurrences of color patterns in Devonian articulate brachiopods. Journal of Paleontology 62, 53-59.

Boettinger, A., Ermentrout, B. \& Oster, G. 2009. The neural origins of shell structure and pattern in aquatic molluscs. PNAS 106, 6837-6842. DOI 10.1073/pnas.0810311106

BroderiP, W. 1839. Genus Phragmoceras. In MurChISON, R.I. The Silurian system founded on geological researches in the counties of Salop, Hereford, Radnor, with descriptions of the coal fields and overlying formations, Part I. 768 pp. John Murray, London.

Clarke, A.H. 1978. Polymorphism in marine molluscs and biome development. Smithsonian Contributions to Zoology 274, 1-14.

Cook, L.M. 1998. A two-stage model for Cepaea polymorphism. Philosophical Transaction of the Royal Society London B 353, 1577-1593. DOI 10.1098/rstb.1998.0311

Cowen, R., Gertman, R. \& Wiggett, G. 1973. Camouflage patterns in Nautilus, and their implications for cephalopod paleobiology. Lethaia 6, 201-214.

DOI 10.1111/j.1502-3931.1973.tb01193.x

Cox, L.R. 1960. Gastropoda - general characteristic of Gastropoda, 84-168. In Moore, R.C. (ed.) Treatise on invertebrate paleontology, Part I, Mollusca 1. Geological Society of America \& University of Kansas Press, Lawrence.
Cox, L.R. 1969. General features of Bivalvia, 2-129. In Moore, R.C. (ed.) Treatise of invertebrate paleontology, part N, Vol. I, Mollusca 6, Bivalvia. Geological Society of America \& University of Kansas Press, Lawrence.

Ferretti, A. \& KŘiž, J. 1995. Cephalopod limestone biofacies in the Silurian of the Prague Basin, Bohemia. Palaios 10(3), 240-253. DOI 10.2307/3515255

Foerste, A.F. 1926. Actinosiphonate, trochoceroid and other cephalopods. Denison University Bulletin, Journal of the Scientific Laboratories 22, 285-383.

FoERste, A.F. 1930. The color patterns of fossil cephalopods and brachiopods, with notes on gastropods and pelecypods. Contribution from the Museum of Paleontology University of Michigan 3, 109-150.

Gould, S.J. \& Lewontin, R.C. 1979. The spandrels of San Marco and the Panglossian paradigm: a critique of the adaptationist programme. Proceedings of the Royal Society of London B 205, 581-598. DOI 10.1098/rspb.1979.0086

Habe, T. \& Okutani, T. 1988. A new subspecies of living Nautilus (Cephalopoda, Nautiloidea) from the Sulu Sea. Venus Japanese Journal of Malacology 47, 91-94.

Hedström, H. 1917. Üeber der Gattung Phragmoceras in der Obersilurformation, Gotlands. Sveriges Geologiska Undersökning, Ser. C 15, 1-35.

HoAGLAND, K.E. 1977. A gastropod color polymorphism: one adaptive strategy of phenotypic variation. Biological Bulletin 152, 360-372. DOI 10.2307/1540424

HoARE, R.D. 1978. Annotated bibliography on preservation of color patterns of invertebrate fossils. The Compass of Sigma Gamma Epsilon 55, 39-64.

Holland, C. \& Stridsberg, S. 2004. Specific representation of the Silurian cephalopod genus Phragmoceras in Gotland and Britain. GFF 26, 301-310.

Hyatт, A. 1894. Phylogeny of an acquired characteristic. American Philosophical Society Proceedings 32, 349-647.

Hyatт, A. 1900. Cephalopoda, 502-592. In Zittel, K.A. \& Eastman, C.R. (eds) Textbook of Palaeontology, vol. 1. 839 pp. Macmillan and Co., Boston.

Klug, C., Brühwiler, T., Korn, D., Schweigert, G., Brayard, A. \& TilsLEy, J. 2007. Ammonoid shell structures of primary organic composition. Palaeontology 50, 1463-1478. DOI 10.1111/j.1475-4983.2007.00722.x

Kobluk, D.R. \& Mapes, R.H. 1989. The fossil record, function and possible origins of shell color Patterns in Paleozoic Marine invertebrates. Palaios 4, 63-85.

DOI $10.2307 / 3514734$

KŘiž, J. 1992. Silurian field excursion: Prague Basin (Barrandian), Bohemia. National Museum of Wales, Geological Series $13,1-111$.

Manda, ك̌ 2007. New Silurian nautiloids Phragmoceras Broderip, 1839, and Tubiferoceras Hedström, 1917, from the Prague Basin (Bohemia). Bulletin of Geosciences 82(2), 119-131. DOI 10.3140/bull.geosci.2007.02.119

MANDA, Š. 2008. Palaeoecology and palaeogeographic relations of the Silurian phragmoceratids (Nautiloidea, Cephalopda) of the Prague Basin (Bohemia). Bulletin of Geosciences 83(1), 39-62. DOI 10.3140/bull.geosci.2008.01.039

MANDA, Š. \& FRÝDA, J. 2010. Silurian-Devonian boundary events and their influence on cephalopod evolution: evolutionary sig- 
nificance of cephalopod egg size during mass extinctions. Bulletin of Geosciences 85(3), 513-540.

DOI 10.3140/bull.geosci.1174

Manda, Š. \& Turek, V. 2009a. A Silurian oncocerid with preserved colour pattern and muscle scars (Nautiloidae). Bulletin of Geosciences 84(4), 755-766.

DOI 10.3140/bull.geosci.1168

MANDA, Š. \& TurEK, V. 2009b. Minute Silurian oncocerids with unusual colour pattern (Nautiloidea). Acta Palaeontologica Polonica 54, 503-512. DOI 10.4202/app.2008.0062

MAPES, R.H. \& DAVIS, R.A. 1995. The color pattern on a Cretaceous Nautiloid from South Dacota. Journal of Paleontology 69, 785-786.

MAPES, R.H. \& DAVIS, R.A. 1996. Color patterns in ammonoids, 103-127. In Landman, N. (ed.) Ammonoid Paleobiology. Topic in Geobiology 13. Plenum Press, New York.

MaPes, R.H. \& Evans, T.S. 1995. The color pattern on a Cretaceous Nautiloid from South Dacota. Journal of Paleontology 69, 785-786.

MAPES, R.H. \& HoARE, R.D. 1987. Annotated bibliography for preservation of color patterns of invertebrate fossils. The Compass of the Earth Science Journal of Sigma Gamma Epsilon $65,12-17$.

MAPES, R.H. \& SCHNECK, W. 1987. The oldest ammonoid "colour" patterns: descriptions, comparison with Nautilus, and implications. Palaeontology 30, 299-309.

Miller, A.K. \& Furnish, W.M. 1937. Paleoecology of the Paleozoic Cephalopoda. Report of the Committee on Paleoecology 1936-1937, 54-63.

REIMCHEN, T.E. 1978. Substratum heterogenity, crypsis, and colour polymorphism in an intertidal snail (Littorina marinae). Canadian Journal of Zoology 57, 1070-1085. DOI 10.1139/z79-135

RuEdemann, R. 1921. On color bands in Orthoceras. Bulletin New York State Museum 227, 63-130.

SAunders, W.B. 1987. The species of Nautilus, 35-52. In SAunders, W.B. \& Landman, N.H. (eds) Nautilus. The Biology and Paleobiology of a Living Fossil. Plenum Press, New York \& London.

Signor, P.W. \& BRETT, C.E. 1984. The mid-Paleozoic precursor to the Mesozoic marine revolution. Paleobiology 10, $229-245$.

Stenzel, H.B. 1964. Living Nautilus, 59-93. In Moore, R.C. (ed.) Treatise on Invertebrate Paleontology, Part K, Mollusca 3. The University of Kansas Press, Lawrence.

STRIDSBERG, S. 1985. Silurian oncocerids cephalopods from Got land. Fossils and Strata 18, 1-65.

Sun, Y.L., Boucot, A.J., Blodgett, R.B. \& Ran, W.Z. 1999. Color pattern on a martiniid brachiopod from South China. Journal of Paleontology 73, 973-976.

SwAN, A.R.H. \& SAUNDERS, W.B. 1987. Morphological variation in Nautilus from Papua New Guinea, 85-103. In SAUNDERS, W.B. \& Landman, N.H. (eds) Nautilus. The biology and Paleobiology of a living fossil. Plenum Press, New York \& London.

Sweet, W.C. 1964. Nautiloidea-Oncocerida, 277-319. In Moore, R.C. (ed.) Treatise on Invertebrate Paleontology, Part K, Mollusca 3, Cephalopoda. Geological Society of America \& The University of Kansas Press, Boulder \& Colorado.

Teichert, C. 1964. Morphology of the hard parts, 13-59. In Moore, R.C. (ed.) Treatise on invertebrate paleontology, part K, Mollusca 3. The University of Kansas Press, Lawrence.

TuREK, V. 1990. Color patterns on Silurian and Devonian cephalopods of Central Bohemia, 81. In Abstracts $3^{\text {rd }}$ Symposium of cephalopods: Present and past. Lyon.

TUREK, V. 2009. Colour patterns in Early Devonian cephalopods from the Barrandian Area: Taphonomy and taxonomy. Acta Palaeontologica Polonica 54, 491-502. DOI 10.4202/app.2007.0064

TUREK, V. \& MANDA, Š. 2010. Variability of colour pattern and shell malformations in Silurian nautiloid Peismoceras Hyatt, 1884. Journal of the National Museum, Natural History 179, 171-178.

VermeIJ, G.J. 1987. Evolution and escalation. 527 pp. Princeton University Press, Princeton.

WARD, P.D. 1987. Natural history of Nautilus. 263 pp. Allen \& Unwin, Boston.

WARD, P. \& SAunders, W.B. 1997. Allonautilus: A new genus of living nautiloid cephalopod and its bearing on phylogeny of the Nautilida. Journal of Paleontology 71, 1054-1064.

Ward, P., Stone, R., Westermann, G. \& Martin, A. 1977. Notes on animal weight, cameral fluids, swimming speed, and color polymorphism of the cephalopod Nautilus pompilius in the Fiji Island. Paleobiology 3, 377-388.

Westerman, G.E.G. 1998. Life habits of nautiloids, 263-298. In Savazi, E. (ed.) Functional morphology of the invertebrate skeleton. John Wiley, London. 